\title{
Case Reports
}

\section{A case of utero-vaginal prolapse presenting at birth}

\author{
*Sankha Srinath Kahawala Jayasinghe ${ }^{1}$, Anuradha Sanjaya Liyanage ${ }^{2}$ \\ Sri Lanka Journal of Child Health, 2019; 48(3): 259-260 \\ DOI: http://dx.doi.org/10.4038/sljch.v48i3.8763 \\ (Key words: Neonatal, utero-vaginal prolapse)
}

\section{Introduction}

Utero-vaginal prolapse very uncommonly presents at birth ${ }^{1}$. It is caused by weakness of ligaments supporting the uterus ${ }^{1}$. Neonatal utero-vaginal prolapse (NUP) is associated with spina bifida in $85 \%$ of cases $^{1}$. NUP is such a rare condition that not a single case has been reported in the Sri Lankan setting and not more than 25 cases have been reported in English literature to date to the best of our knowledge.

\section{Case report}

A term baby girl weighing $3320 \mathrm{~g}$ was born by normal vaginal delivery to a 34 year old mother of 2 healthy children. The antenatal history was normal and birth was uneventful with normal Apgar scores. A ruptured lumbosacral myelomeningocele was found at delivery. Examination showed normal lower limb neurology, urinary and faecal incontinence and uterovaginal prolapse. The urethral orifice and anus were normal. The Apgar scores were normal at 1 and 5 minutes. Her occipito-frontal circumference (OFC) at birth was $33 \mathrm{~cm}$ and brain and abdominal sonography were normal. The myelomeningocele was closed on day 2 .

She was catheterised using a size 6 Foley's urethral catheter. The prolapse was reduced by gripping it and gently pushing it inwards after lubricating with lignocaine gel. The 2 lower limbs were strapped together with crepe bandage that was applied in a mermaid fashion from buttocks to lower legs sparing the anus for defecation to prevent recurrence on straining (Figure 1). Amidst this she

\footnotetext{
${ }^{1}$ Registrar in Paediatrics, Teaching Hospital, Kandy, Sri Lanka, ${ }^{2}$ Consultant Paediatric Surgeon, Teaching Hospital, Kurunegala, Sri Lanka *Correspondence: sankhasrinath@gmail.com$$
\text { (iD) }
$$$$
\text { orcid.org/0000-0002-2069-1668 }
$$

(Received on 09 August 2017: Accepted after revision on 15 September 2017)

The authors declare that there are no conflicts of interest

Personal funding was used for the project.

Open Access Article published under the Creative

Commons Attribution CC-BY cC (†) License
}

had a recurrence of the prolapse and a small lubricated vaginal pack had to be inserted after reducing the prolapse again and crepe bandage was re-applied in the same manner. Both catheter and vaginal pack were removed after 72 hours and there was no recurrence thereafter.

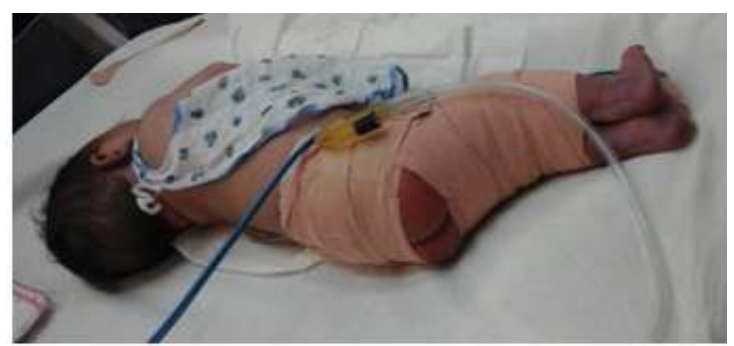

Figure 1: Conservative management of neonatal utero-vaginal prolapse in mermaid fashion

\section{Discussion}

Though mostly found in babies with spina bifida, NUP is also found in babies with intrauterine growth retardation ${ }^{2}$. Early treatment of NUP is crucial for a satisfactory outcome. Several conservative and operative modalities are used in treatment of NUP. Conservative treatment has a success rate exceeding $90 \%{ }^{1}$. After initial digital reduction, NUP tends to recur when the intraabdominal pressure rises during crying or straining. We overcame this problem with the insertion of a small vaginal pack, which measure is supported by many authors in the literature ${ }^{3,4,5}$. Surgical procedures have been used when conservative measures failed ${ }^{1}$.

\section{References}

1. Hyginus EO, John CO. Congenital uterovaginal prolapse present at birth. Journal of Surgical Technique and Case Report 2013; 5(2): 89-91.

https://doi.org/10.4103/2006-8808.128741

PMid: 24741427 PMCid: PMC3977332

2. Paediatric surgery update 8. Vol.24 No.1 January 2005. Available from: http://home.coqui.net/titolugo/PSU24105. pdf [Accessed 2017 August 09].

3. Lockwood G, Durkee C, Groth T. Genital prolapse causing urinary obstruction and 
hydronephrosis in a neonate: A case and review of the literature. Journal of Neonatal Surgery 2012; 1(3):39.

PMid: 26023398 PMCid: PMC4420420

4. Ellis JB, Boes EG. Genital prolapse. South African Medical Journal 1986; 69:836. PMid: 3715670
5. Loret de Mola JR, Carpentar SE. Management of genital prolapse in neonate and young women. Obstetrical and Gynecological Survey 1996; 51:25360.

https://doi.org/10.1097/000062541996040 00-00022 